\author{
Aldona Małgorzata DEREŃ 1 \\ Jan SKONIECZNY ${ }^{2}$
}

\title{
THE YELLOW ORGANIZATION AS AN INTEGRATIVE STAGE IN THE F. LALOUX' ORGANIZATION MODEL
}

\begin{abstract}
This paper describes the organisation's teal model developed by F. Laloux. The authors analysed this model in terms of opportunities and possibilities of its implementation in Polish enterprises. This analysis allowed the authors to distinguish the Yellow organisation located between the Orange and Green organisations.

The goal of such an organisation is dynamic development and profit. It has a simplified and flattened hierarchy demonstrating that effective management is based on the diligence and passion of employees as well as creative leadership. The distinguished type of organisation is the stage preceding the development of a teal organisation. The research methods included the analysis of theoretical aspects and opinions of managers who implemented the model of a teal organisation for their practice.
\end{abstract}

Keywords: teal organisation, management, style, start-up.

\section{INTRODUCTION}

Contemporary conditions of business development determine globalization, changes in communication processes, the use of modern technologies and IT tools, and changes in the preferred social values. These changes have a direct impact on the functioning of the organization. Understanding the essence of these changes is to harmonize goals, structures, and styles of management that take into account new approaches and models. The idea of a teal organization is such an innovative model.

The creator of the Teal organization model is F. Laloux ${ }^{3}$, who distinguished five management models, giving each of them a symbolic color. The first is Red this color is characteristic of organizations such as mafia or street gangs. The binder of these organizations is fear and the purpose of keeping subordinates in check.

An Amber organization is characterized by a rigid hierarchy with a division into formal roles, where the most important value is stability. This form of management exists, for example, in armies or churches. Another model is an Orange organization that resembles a machine aimed at achieving goals. Then a Green organization in which the leader enters

\footnotetext{
${ }^{1}$ Aldona Małgorzata Dereń, DSc PhD, Associate Prof., Faculty of Computer Science and Management, Wrocław University of Science and Technology, Wybrzeże St. Wyspiańskiego 27, 50-370 Wrocław; e-mail: aldona.deren@pwr.edu.pl. ORCID: 0000-0002-2377-4573.

2 Jan Skonieczny, PhD Eng., Faculty of Computer Science and Management, Wrocław University of Science and Technology, Wybrzeże St. Wyspiańskiego 27, 50-370 Wrocław; e-mail: jan. skonieczny@pwr.edu.pl. ORCID: 0000-0002-1027-991X.

3 The term "turquoise organization" has been used in Polish literaturę, e.g.: (Laloux, 2015).
} 
the role of a mentor, teacher, and not a dictator. Such an organizational model is close to, for example, social movements. It is followed by Teal organization - the highest stage in the organization model. The all models proposed and marked with a specific color have been ordered according to the style of management - from the most authoritarian to the most democratic. The teal organization was presented by F. Laloux as the highest level of awareness in the management of the organization. From the cognitive point of view, it is interesting how this model could be implemented in the entrepreneurial conditions in Poland.

The aim of the article is to analyze and evaluate the F. Laloux “ Teal organization in the context of opportunities and barriers to the development of this model in Polish enterprises. The authors' experiences in the field of research on organizational creativity and management of intellectual property resources indicate that even in innovative enterprises, the hierarchical structure is not abandoned.

Therefore, we believe that one more stage of organization model is needed, which we placed between the Orange and the Green organization. It is a Yellow organization based on passion, cooperation, and openness to its environment. These three elements have a decisive impact on building the awareness of the responsibility that must be taken by all employees.

\section{MODEL TEAL ORGANIZATION AS A NEW PARADIGM IN MANAGEMENT THEORY}

In 2014, F. Laloux published a book on Reinventing Organization. It presents the concept of Teal organization as a new paradigm in management theory, where we have a division of work, formal managerial authority, unity of command and leadership, subordination of personal interests to the general interest, and hierarchy and organizational structures guarantee effective organization management. According to F. Laloux, the "Teal organization" is another type in the evolution of the organization's development.

F. Laloux describes the history of humanity as an evolutionary process consisting of many stages. Referring to the work of the philosopher Ken Wilber, he describes the five stages of human consciousness and assumes that organizations evolve in accordance with the same stages. By describing each of these stages and the corresponding organizational model, he uses names and colors to describe them. These are: Red (impulsive); Amber (conformist); Orange (achievement); Green (pluralistic); Teal (evolutionary). The description of the distinguished types of organizations is presented in Table 1.

The four basic types of organizations distinguished by F. Laloux - a Red, Amber, Orange and Green organization, although significantly different from each other, have certain common features. Common hierarchical management structure, formalized decision process, and its control, as well as formalized ways of setting plans and budgets, are common. However, the proposed by him new model - the Teal organization is based on three basic pillars (Laloux, 2015):

- self-management (self-organizing teams): lack of hierarchical structure and mid-level management; minimum number of staff units, the leader is selected and accepted by employees; decentralization of management decisions; trust-based management;

- wholeness - every employee has the opportunity to use their talents and talents at work in a turquoise organization. Employees have the opportunity to share knowledge and freely express their opinions and their creativity; 
- evolutionary purpose - purpose is determined in the course of joint discussion and are adapted to the current needs and the situation in which the organization is located. The Teal organization does not formulate rigid purposes from the perspective of 2 or 5 years. Market volatility and unpredictable future cause that Teal organizations do not traditionally formulate their strategy way by stiffly setting purposes and means, but analyze the opportunities that are the basis for setting purposes and actions in an ever-changing situation. Purpose takes the form of intentions, and the strategy is a synthesis of order (strategy considered) and chaos (emerging strategy) (Strategor, Zarzadzanie firma. Strategie..., 1995).

Table 1. Types of contemporary organizations according to F. Laloux

\begin{tabular}{|c|c|c|c|c|}
\hline $\begin{array}{l}\text { The type of } \\
\text { organization }\end{array}$ & Characteristic & $\begin{array}{l}\text { Key success } \\
\text { factors }\end{array}$ & Metaphor & Examples \\
\hline Red organization & $\begin{array}{l}\text { Permanent exercise } \\
\text { of strong authority } \\
\text { by the leader to keep } \\
\text { people in check. } \\
\text { The organization is } \\
\text { based on fear. } \\
\text { A highly relative } \\
\text { mode of opera- } \\
\text { tion.Concentration } \\
\text { on short-term goals. }\end{array}$ & $\begin{array}{l}\text { - distribution of } \\
\text { receipts and spoils } \\
\text { - power, supremacy }\end{array}$ & wolf pack & $\begin{array}{l}\text { - mafia } \\
\text { - street gangs } \\
\text { - tribal militias }\end{array}$ \\
\hline $\begin{array}{l}\text { Amber } \\
\text { organization }\end{array}$ & $\begin{array}{l}\text { Highly formalized } \\
\text { roles in the hierar- } \\
\text { chical pyramid. } \\
\text { Top-down manage- } \\
\text { ment and control } \\
\text { (what and how). } \\
\text { Stability is the most } \\
\text { important value pro- } \\
\text { vided by rigorous } \\
\text { processes. } \\
\text { The future is repeat- } \\
\text { ing the past. }\end{array}$ & $\begin{array}{l}\text { - formal roles (stable } \\
\text { and scalable) } \\
\text { - processes (long- } \\
\text { term perspective) }\end{array}$ & army & $\begin{array}{l}\text { - The Catholic } \\
\text { church } \\
\text { - military } \\
\text { - most government } \\
\text { agencies } \\
\text { - public schools } \\
\text { systems }\end{array}$ \\
\hline $\begin{array}{l}\text { Orange } \\
\text { organization }\end{array}$ & $\begin{array}{l}\text { The goal is to over- } \\
\text { come rivals, achieve } \\
\text { profit and continu- } \\
\text { ous growth. Innova- } \\
\text { tion is the key to } \\
\text { success on the mar- } \\
\text { ket. Management by } \\
\text { objectives (manage- } \\
\text { ment and control } \\
\text { over "what", free- } \\
\text { dom in relation to } \\
\text { "how"). }\end{array}$ & $\begin{array}{l}\text { - innovations } \\
\text { - responsibility } \\
\text { - meritocracy }\end{array}$ & intelligent machine & $\begin{array}{l}\text { - multinational } \\
\text { companies } \\
\text { - charter schools }\end{array}$ \\
\hline
\end{tabular}


Table 1 (cd.). Types of contemporary organizations according to F. Laloux

\begin{tabular}{|c|c|c|c|c|}
\hline $\begin{array}{c}\text { The type of } \\
\text { organization }\end{array}$ & Characteristic & $\begin{array}{l}\text { Key success } \\
\text { factors }\end{array}$ & Metaphor & Examples \\
\hline $\begin{array}{l}\text { Yellow } \\
\text { organization }\end{array}$ & $\begin{array}{l}\text { The goal is dynamic } \\
\text { development and } \\
\text { profit: } \\
\text { - simplified and flat- } \\
\text { tened hierarchy; } \\
\text { - management based } \\
\text { on pursuing passion, } \\
\text { acquiring skills and } \\
\text { a creative leader; } \\
\text { - limited human and } \\
\text { financial resources } \\
\text { developed as the } \\
\text { organization grows }\end{array}$ & $\begin{array}{l}\text { - knowledge } \\
\text { - creation } \\
\text { - expansiveness }\end{array}$ & $\begin{array}{l}\text { - Big Data } \\
\text { - application } \\
\text { software }\end{array}$ & Start-ups \\
\hline Green organization & $\begin{array}{l}\text { They function in the } \\
\text { classic structure of } \\
\text { the pyramid, but } \\
\text { concentrate on cul- } \\
\text { ture and empower- } \\
\text { ment in order to } \\
\text { achieve extraordi- } \\
\text { nary motivation of } \\
\text { employees. }\end{array}$ & $\begin{array}{l}\text { Organizations are } \\
\text { driven by culture: } \\
\text { - empowerment } \\
\text { - a culture based on } \\
\text { the value } \\
\text { - stakeholder model }\end{array}$ & family & $\begin{array}{l}\text { ecological and so- } \\
\text { cial organizations }\end{array}$ \\
\hline Teal organization & $\begin{array}{l}\text { The work is based } \\
\text { on the paradigm of } \\
\text { organizing team- } \\
\text { work, which gives } \\
\text { each person (not an } \\
\text { employee) a sense of } \\
\text { the meaning of life, } \\
\text { allows for develop- } \\
\text { ment, offers space } \\
\text { for their creativity } \\
\text { and innovation. De- } \\
\text { cisions in such an or- } \\
\text { ganization are made } \\
\text { by people who know } \\
\text { the subject and have } \\
\text { predispositions, of- } \\
\text { ten after consulting } \\
\text { others, and the rest } \\
\text { of the team trusts } \\
\text { them. }\end{array}$ & $\begin{array}{l}\text { Organizations pow- } \\
\text { ered by: } \\
\text { - self-management } \\
\text { - full identity } \\
\text { - your own life (evo- } \\
\text { lution of the goal) }\end{array}$ & $\begin{array}{l}\text { human and other liv- } \\
\text { ing organisms }\end{array}$ & $\begin{array}{l}\text { socialized organi- } \\
\text { zations }\end{array}$ \\
\hline
\end{tabular}

Source: (Laloux, 2015).

The model of the Teal organization proposed by F. Laloux is a projection reminding the model of ideal patterns. G. Nadler (Kisielnicki, 1986) used for design systems and develop forecasting techniques used in information systems based on a database, improve organization and management as well as technical design. This model is characterized by a departure from the need to analyze existing conditions and focus on determining the target state. A similar approach can be found in the Teal organization model. 


\section{OPPORTUNITIES AND BARRIERS TO CREATING TEAL ORGANIZATIONS IN POLISH ENTERPRISES}

It is difficult to disagree with the statement that the development and functioning of each organization are constantly evolving. In the approach proposed by F. Laloux, the Teal organization model is the next stage of this evolution, which is accompanied by the change and development of human consciousness. Let us not forget, however, that the subject of the analysis presented in his book is enterprises operating in a well-formed and mature social market economy (the USA, the Netherlands, Germany, France). The question is, do the economy in Poland, which only after 1989 has created the basis of activity for the development of market structures, is ready to introduce the Teal management model? (Jeznach, 2017). The answer to this question is not unambiguous. On the one hand, in Poland there are of companies that introduce turquoise management, e.g. the LeaNCe and Notiustshop (Jeznach, 2017), Krakow kindergarten, in which children design children's clothing, and their neck, IT company Kamsoft Podlasie from Zambrów, producer of labels and packaging Marco from Gliwice, and the service company Brewa from Kalisz, the company installing solar cells Maxim, the company Zielona Wieża, and the producer of labels and packaging Marco from Gliwice (Blikle, 2017). On the other hand, the new management style is perceived by owners and managers as to their position as a leader in the company. Those who prefer leadership and authoritarian attitudes argue that this is the most effective style of leadership. The social research, carried out in Poland by J.T. Hryniewicz, shows that not only managers but employees treat new ideas and their involvement in their work as a threat to themselves (sic!) (Hryniewicz, 2017). Polish employees appreciate the most: job security, efficient organization, good relations with managers. On the other hand, they value low individual achievements that violate the formal hierarchy, adopted prestige and popular opinions. A similar mentality is noticed in the behavior of the managerial staff in Poland. Perhaps the reason for such attitudes is the socalled "peasant mentality":

“(...) in our collective experience, attitudes, customs and procedures proper to the management of truly free people, nor the attitude of truly free employees are not used. That is why corporate employees feel best by following orders, and bosses are best placed in authoritarian management" (Jeznach, 2017). According to W. Eichelberger: "(...) the most common picture that can be seen in Polish companies is the manager who has «stick and carrot» among passive people, (...)". "That is why new management trends and a modern culture of business organizations are hard to root on Polish soil. (...). Either the bosses and owners must see that they are freed from their "slaves" or "slaves" must rebel and fight for freedom" (Jeznach, 2017).

Equally critical about the introduction of the Teal organization in Poland is expressed by J. Santorski, who claims that they are still a myth because most enterprises derive from the paradigm of the farm, dictatorship, hierarchy:

"From the point of view of our mentality, it is difficult for Teal companies. The Pole, however, has such a conviction that "if there is no boss, then everyone is stupid, and suddenly - we all can be "bosses"? And further: "Nevertheless, the world is going this way [Teal organization] and if even the army evolves towards" mission commands", flexible teams, then this kind of openness is inevitable in the best sense 
of the word" (Santorski, https://www.impel.pl/.../jacek-santorski-turkusowe-firmyw-polsce-sa-jeszcze-mitem).

\section{YELLOW ORGANIZATION AS AN INTEGRATIVE STAGE IN ORGANIZATION MANAGEMENT SYSTEM}

The quoted opinions and conclusions from the research indicate that the main obstacle in creating the turquoise organization in Polish enterprises are mental barriers. In the opinion of the authors, a change of this mentality is possible, but it would require passing organizations through stage called by authors "Yellow organization" which is placed between Orange and Green organization (see Table 1). In our opinion, this new stage can be the supplement the integrative stage in the F. Laloux' organization model. Which in the case of enterprises in Poland seems to be a natural and obvious stage in the development of the organization. At this stage, there may be a change in thinking about the company and its functioning on the market.

The Yellow organization proposed by the authors is an intermediate stage between the Orange organization and the Green organization. The yellow organization, compared to the Orange organization, is a more democratized structure, which is manifested by the fact that it is employees who define the goals and ways of their implementation, but these goals are formulated by the managers. Compared to the Green organization, which is based on the broadly understood cooperation with the environment, the Yellow organization uses market competition as a factor in the development of its operations. In the Yellow organization, the driving force its development are: creativity, modern knowledge, and technology as well as scalability of innovations. Such an organization is startups defined as agile project management, creative and innovative approaches for generating and implementing creative ideas, designing business models financed and supported mainly by external capital, including min. investment funds, business angels or crowdfunding. In this approach, the startup is a temporary organization that searches for a scalable, repeatable and profitable business model (Blank, Dorf, 2013).

\section{CONCLUSIONS}

The model of the Teal organization presented by F. Laloux is based on three concepts concerning: organizational structures, practices, and culture. These are:

- self-management - resignation from the traditional hierarchical structure to maximize the independence of each employee;

- wholeness striving for fullness - enabling self-realization and full use of the potential of employees;

- orientation on the evolutionary purpose of the organization - focusing on the goal more than on profits.

According to F. Laloux, the motivational power of these organizations is a management method based on trust and consultation and the empowerment of the employee. The Teal organization does not completely reject the existing forms of motivating but only reverses hitherto logic and order.

"We do not strive for recognition, success, wealth and belonging to in order to lead a good life, we strive for a well-lived life, and its effect may become recognition, success, wealth and love" (Laloux, 2015). 
The authors of this publication believe that the transformation towards a Teal organization is possible and real. However, in the conditions of Polish entrepreneurship, it is necessary to go through the Yellow organization stage. This stage - according to the authors - favors the shaping and development of human consciousness, creativity, and entrepreneurship. If we treat startups as yellow organizations that evolve towards a green organization characterized by a culture based on values and respect for people, then the chances of getting closer to the ideal of the Teal organization are possible in practice.

\section{REFERENCES}

Beauchamp, M., Krysztofiak-Szopa, J., Skala, A. (2018). Polskie startupy. Raport 2018. Warszawa: Fundacja Startup Poland.

Blank, S., Dorf, B. (2013). Podręcznik startupu. Budowa wielkiej firmy krok po kroku. Gliwice: Helion.

Blikle, J. (2017). Doktryna jakości. Rzecz o turkusowej samoorganizacji. Gliwice: Helion.

Hryniewicz, J.T. (2017). Stosunki pracy w polskich organizacjach. Warszawa: Wydawnictwo Naukowe Scholar.

Jeznach A. (2017). Szef, który ma czas. Ewolucja zarządzania - dziennik budowy turkusowej organizacji. Gliwice: Helion.

Kisielnicki J. (1986). Metody systemowe. Warszawa: PWN.

Laloux, F. (2015). Pracować inaczej. Nowatorski model organizacji inspirowany kolejnym etapem rozwoju ludzkiej świadomości, tł. z ang. M. Konieczniak. Wrocław: Studio Emka.

- (2014). Reinventing Organization, Foreword Ken Wilber. Fabruary 10.

Santorski, J., Turkusowe firmy w Polsce sa jeszcze mitem [Access: 18.08.2019]. Access on the internet: https://www.impel.pl/.../jacek-santorski-turkusowe-firmy-w-polsce-sa-jeszcze-mitem Strategor (1995). Zarzadzanie firma. Strategie, struktury, decyzje, tożsamość. Warszawa: PWE. Suchodolska M., Kapitalizm po polsku: folwark ma się dobrze, „Dziennik Gazeta Prawna”, z 6.06.2014 [Access: 19.07.2019]. Access on the internet: http://biznes.gazetaprawna.pl/ artykuly/801950,kapitalizm-po-polsku-folwark-ma-sie-dobrze.html

DOI: $10.7862 /$ rz.2019.hss.34

The text was submitted to the editorial office: July 2019.

The text was accepted for publication: December 2019. 
